\title{
A trágyázás hatása a talaj szervesanyag-tartalmára és agronómiai szerkezetére vetésforgókban és kukorica monokultúrában
}

\author{
TÓTH ZOLTÁN és KISMÁNYOKY TAMÁS
}

Veszprémi Egyetem Georgikon Mezőgazdaságtudományi Kar, Keszthely

Az elemi talajszemcsék (mechanikai frakciók) a talajok jelentős hányadában természetes állapotban nem külön-külön, hanem szerves és ásványi kolloidokkal összeragasztva, sajátságos képződményeket, aggregátumokat, ún. szerkezeti elemeket alkotva találhatók a talajokban. A talaj szerkezeti állapota, a szerkezeti elemek nagysága, valamint vízzel és a művelőeszközökkel szembeni ellenállósága a talaj agronómiai értékének, termékenységének fontos jellemzője (,agronómiai talajszerkezet”) (VÁRALLYAY, 1993).

A talajok termőrétegében állandóan képződik, bomlik és átalakul a szerves anyag, ezért a talaj szervesanyag-tartalma bizonyos határok között növekedhet illetve csökkenhet (STEFANOVITS, 1992). Az irodalmi források alapján ismert, hogy számos olyan tényező amely a talaj szervesanyag-tartalmát növeli, ezen keresztül közvetve kedvező hatást gyakorolhat a talaj szerkezetére is (TISDALE \& Nelson, 1966; SiPOS S., 1978; Allison, 1973; TATE, 1987; YANG \& WANDER, 1998).

UHLEN (1991), CoLLINS et al. (1992), valamint HAVLIN et al. (1990) a vetésforgók jelentős szerepét hangsúlyozzák a talaj szervesanyag-tartalmának fenntartásában, illetve növelésében.

Egyes szerzők véleménye szerint a tápanyagadagok növekedése - beleértve a mütrágyázást is - szintén növeli a talaj szervesanyag-tartalmát (HAVLIN et al., 1990; CAMPBELl \& ZENTNER, 1993; SiPOS G., 1978a; KEMENESY, 1961; TisDALE \& NELSON, 1966 stb.). Mások viszont ezzel ellentétes tendenciákat figyeltek meg (KOVÁCS \& FÜLEKY, 1994). NÉMETH (1996) az OMTK hálózatának nyolc helyén végzett talaj szervesanyag-tartalom vizsgálati eredmények alapján arról számol be, hogy a tartós, különböző adagú mütrágyázásnak nem volt humusztartalom-csökkentő hatása a kontrollhoz viszonyítva az eltelt húsz év alatt, a mosonmagyaróvári öntéstalajon pedig bizonyos mértékủ humusztartalom-növekedést (0,17-0,20 H \%) regisztráltak. KovÁTS és ANTAL (1992), 
valamint DEBRECZENI (1994) felhívják a figyelmet arra, hogy a szakszerütlen mütrágyázással a talaj szerkezeti állapotát illetően árthatunk is.

SARKADI (1975) véleménye szerint egy tenyészidő alatt a talaj szerves anyagának 1-2\%-a (néha $3 \%$-a) bomlik le, aminek mértéke függ a szerves vegyületek minőségétől, valamint a talaj-mikroorganizmusok tevékenységétőll. Az említett tényezők befolyásolhatók az alkalmazott földmüvelési, talajmüvelési és trágyázási rendszerekkel egyaránt. GYőRFFY (1975) vizsgálataiból kitünik, hogy a szervesanyag-tartalom alakulására elsősorban a talajművelés rendszerének, másodsorban a trágyázásnak, harmadsorban pedig a vetésforgónak van jelentősége.

A tápanyagellátás talajszerkezetre gyakorolt hatása részben a növények gyökérzetén keresztül érvényesül. Mivel az egyes növények gyökérzetük jellegétől és a területen visszahagyott szerves anyag minőségétől függően különbözően befolyásolhatják a talaj szerkezetét (FERTS, 1955; KEMENESY, 1961; FEKETE, 1958; CARON et al., 1992; ARMBRUST et al., 1982; ElLSWORTH et al., 1991; BATHKA \& BLAKE, 1984), ebből adódóan a különböző földművelési rendszerek is egymástól eltérő hatást gyakorolhatnak arra (VILJAMSZ, 1950; CSERHÁTI, 1905).

A talajszerkezet alapvetően meghatározza a talaj pórusrendszerét, ezen keresztül víz- és levegőgazdálkodását, mivel a szerkezeti elemek felépítésétől, illeszkedésétől függ a kisebb-nagyobb hézagok levegö- és vízaránya. SIPOS G. (1978/b) szerint agronómiai szempontból legkedvezőbb az 1-3 mm átmérőjü morzsa. Véleménye szerint ideális szerkezetünek az a talaj tekinthetö, amelyben a morzsafrakció (0,25-10 mm átmérőtartomány) legalább 80 \%-ot képvisel. Hazai talajainkban a morzsák mennyisége $0-70 \%$ között változik.

A talajaggregátumok méret szerinti eloszlása mellett a talajmorzsák tartóssága, a különböző fizikai behatásokkal szembeni ellenállósága is fontos jellemzője a talaj agronómiai értékének, termékenységének (VÁRALLYAY, 1993).

RAIMBAULT és VYN (1991) kukoricában végzett vizsgálataik során azt találták, hogy a talaj porozitása és a vízálló morzsák aránya vetésforgóban kedvezőbb volt, mint monokultúrában.

A talajmorzsák vízállóságát egyes szerzők szerint a talaj szervesanyag-tartalmán és a szerves anyag minőségén (TISDALL \& OADES, 1982; CHURCHMAN \& TATE, 1987; ChENU, 1989; HAYNES \& SWIFT, 1990; stb.) túlmenően a talaj biológiai tevékenysége, a mikroszkopikus gombák és baktériumok által termelt váladékok, szerves ragasztóanyagok is jelentősen befolyásolják (COOK \& ELLIS, 1987; MILLER \& JASTROW, 1992; WRIGHT \& UPADHYAYA, 1998; WRIGHT et al., 1996, 1998, 1999). DVORACSEK és munkatársai (1957) felhívják a figyelmet arra, hogy egyes szerzők arra az álláspontra helyezkednek, hogy nem szabad túlbecsülni a baktériumváladékoknak és a gombamicéliumoknak a morzsák tartósságára gyakorolt befolyását, mert a mikroorganizmusok, illetve váladékaik hatása csak rövid ideig tart, így nem nevezhetö állandónak. 
Vizsgálatainkkal a különböző növényösszetétel és tápanyagadagok, valamint a talaj szervesanyag-tartalma és agronómiai szerkezete közötti összefüggéseket igyekeztünk feltárni.

\section{Anyag és módszer}

A talaj szervesanyag-tartalma és agronómiai szerkezete évről évre csak kis mértékben változó paraméterek, ezért tanulmányozásukra megbízhatóan tartamkísérletekben nyílik lehetőség. Vizsgálatainkat a Veszprémi Egyetem Georgikon Mezőgazdaságtudományi Kar Növény- és Környezettudományi Intézet Kísérleti Telepén végeztük Keszthelyen egy kukorica monokultúra és egy vetésforgó tartamkísérlet kukorica, illetve öszi búza szakaszaiban. A szabadföldi vetésforgó tartamkísérletet 1963-ban Kemenesy Ernő, a kukorica monokultúra kísérletet pedig 1969-ben Kováts András irányításával állították be.

A kísérlet talajtípusa humusszal és foszforral gyengén, káliummal közepesen ellátott Ramann-féle barna erdőtalaj. A talaj főbb jellemzői: humusztartalom 1,6-1,7 \%, AL-oldható $\mathrm{P}_{2} \mathrm{O}_{5}$-tartalom 60-80 mg/kg, $\mathrm{K}_{2} \mathrm{O}$-tartalom 140-160 mg/ $\mathrm{kg}, \mathrm{pH}\left(\mathrm{H}_{2} \mathrm{O}\right) 7,0-7,5, \mathrm{pH}(\mathrm{KCl}) 6,8-7,0$. Az évente átllagosan lehullott csapadék mennyisége: $700 \mathrm{~mm}$, a csapadékos napok száma: 161, az átlagos évi középhömérséklet: $10,8^{\circ} \mathrm{C}$.

A vetésforgós tartamkísérlet két ötszakaszos vetésforgót foglal magában 4-4 ismétlésben, melyek közül az egyik évelő pillangóst tartalmaz (őszi búza-lucerna-lucerna-őszi búza-kukorica), a másik pedig egyéves növényekből áll (őszi búza-zabosbükköny-őszi búza-kukorica-szudánifü). A kísérlet kéttényezős, sávos elrendezésü kísérletként értékelhető, melyben a tápanyagadagok ( $A$ tényezö) és a vetésforgók növényösszetételének ( $B$ tényezö) hatását vizsgáltuk. A tápanyagkezelések négy különböző tápanyagellátási szintet reprezentálnak, melyek évről évre az éppen sorra kerülő növénytől függően változnak, de egy teljes rotáció során (5 év alatt) az egyes vetésforgók azonos kezeléseiben kijuttatott tápanyagadagok megegyeznek egymással ( $a_{1}$ kezelés: kontroll; $a_{2}$ kezelés: $520 \mathrm{~kg}$ NPK/ha/5év; a 3 kezelés: $2080 \mathrm{~kg} \mathrm{NPK} /$ ha/5év; a $a_{4}$ kezelés: 2080 kg NPK $+35 \mathrm{t}$ istállótrágya/ha/5év). Az a kezelésben külön tanulmányozható az $\mathrm{a}_{3}$ kezelésben kijuttatott mütrágyaadagon felül adott istállótrágya hatása. Az istállótrágyát mindkét forgóban ötévente a kukorica elött egy adagban juttatják ki.

A kukorica monokultúra kísérlet szintén kéttényezős, de osztott parcellás elrendezésü kísérlet 4-4 ismétléssel és benne a tápanyagadagok ( $a_{1}$ kezelés: kontroll; $a_{2}$ kezelés: $300 \mathrm{~kg} \mathrm{NPK} / \mathrm{ha} / \mathrm{év} ; \mathrm{a}_{3}$ kezelés: $600 \mathrm{~kg}$ NPK/ha/év; $a_{4}$ kezelés: $900 \mathrm{~kg} \mathrm{NPK} / \mathrm{ha} / \mathrm{e} v)$, valamint a N-mütrágya kijuttatás idejének $\left(b_{1}\right.$ : tavasszal egy adagban, $b_{2}$ : összel egy adagban, $b_{3}$ : tavasszal két adagban) hatása tanulmányozható. 
A kísérletekben mind a kukorica-, mind pedig az őszibúza-parcellák (előveteménytől függetlenül) őszi forgatásos alapművelésben részesülnek, betakarítás után pedig mindkét esetben lehordják a területről a szármaradványokat.

A vizsgálatokhoz ismétlésenként minden vizsgált parcella talajából három részmintát vettünk kézi talajfúróval a $0-30 \mathrm{~cm}$ talajrétegből betakarítás előtt, a kukorica-parcellákon szeptemberben, az őszibúza-parcellákon pedig júniusban. A talaj szervesanyag-tartalmának (humusz) meghatározásához Tyurin módszerét alkalmaztuk (BALLENEGGER \& DI GLÉRIA, 1962). Az agronómiai szerkezet vizsgálata során száraz szitálással vizsgáltuk az aggregátumok méret szerinti eloszlását (por $<0,25 \mathrm{~mm}<$ morzsa $<10 \mathrm{~mm}<$ rög), a talajmorzsák vízállóságának meghatározása pedig nedves szitálással - Kazó módszerével (HEGEDÜS, 1980) - történt. Az eredmények statisztikai megbízhatóságát kéttényezős varianciaanalízissel elemeztük.

\section{A vizsgálati eredmények értékelése}

A talaj szervesanyag-tartalma

A tápanyagadagok növekedésével párhuzamosan növekedett a talaj szervesanyag-tartalma a kukorica monokultúrában és a vetésforgókban egyaránt.

A trágyázatlan kontrollkezeléshez viszonyítva monokultúrában csak a 600 , ill. a $900 \mathrm{~kg} \mathrm{NPK} /$ ha mütrágyakezelés eredményezett szignifikáns növekedést (1. táblázat). Az $\mathrm{NPK}_{600^{-}}$és $\mathrm{NPK}_{900}$-kezelések eredményei között szignifikáns különbség nem figyelhető meg, viszont mindkét kezelésben szignifikánsan na-

1. táblázat

A talaj szervesanyag-tartalma kukorica monokultúrában a tápanyagellátás függvényében (g/kg) (Keszthely, 1996)

\begin{tabular}{|c|c|c|c|c|c|}
\hline \multirow[t]{2}{*}{ N-kijuttatás } & \multicolumn{4}{|c|}{$\begin{array}{c}(2) \\
\text { Tápanyagadagok }\end{array}$} & \multirow[t]{2}{*}{ Átlag } \\
\hline & $\mathbf{a}_{1}$ & $\mathbf{a}_{2}$ & $\mathbf{a}_{3}$ & $\mathbf{a}_{4}$ & \\
\hline a) $\mathrm{N}$ tavasszal egy adagban & 14,30 & 14,92 & 15,45 & 16,15 & 15,21 \\
\hline b) $\mathrm{N}$ ősszel egy adagban & 13,47 & 14,20 & 15,97 & 16,30 & 14,99 \\
\hline c) $\mathrm{N}$ tavasszal két adagban & 13,37 & 14,50 & 15,85 & 15,45 & 14,79 \\
\hline d) Átlag & 13,72 & 14,54 & 15,76 & 15,97 & \\
\hline e) Főátlag & & & & & 15,00 \\
\hline \multicolumn{5}{|l|}{ f) $\mathrm{SzD}_{5 \%}$ bármely két kombir } & 1,70 \\
\hline \multicolumn{5}{|c|}{ g) $\mathrm{SzD}_{5 \%}$ a tápanyagadagok változatai között a N-kijuttatás átlagában: } & 0,98 \\
\hline \multicolumn{5}{|c|}{ h) $\mathrm{SzD}_{5 \%}$ a N-kijuttatás változatai között a tápanyagadagok átlagában: } & \\
\hline
\end{tabular}


gyobb a szervesanyag-tartalom, mint az $\mathrm{NPK}_{300}$-kezelésben. Kukorica monokultúrában tehát kizárólag mütrágyázással is növelhető volt a talaj szervesanyagtartalma, ami vélhetően a nagyobb tápanyagadagok hatására képződött és a talajban visszamaradt nagyobb mennyiségú biomasszatömeggel (gyökér- és tarlómaradványok) magyarázható.

\section{2. táblázat}

A talaj szervesanyag-tartalma vetésforgókban a tápanyagellátás függvényében (g/kg) (Keszthely, 1996)

\begin{tabular}{|c|c|c|c|c|c|}
\hline \multirow[t]{2}{*}{$\begin{array}{l}\text { (1) } \\
\text { Vetésforgók }\end{array}$} & \multicolumn{4}{|c|}{$\begin{array}{c}(2) \\
\text { Tápanyagadagok }\end{array}$} & \multirow[t]{2}{*}{$\begin{array}{l}\text { (3) } \\
\text { Átlag }\end{array}$} \\
\hline & $\mathbf{a}_{1}$ & $\mathbf{a}_{2}$ & $\mathbf{a}_{3}$ & $\mathbf{a}_{4}$ & \\
\hline a) Lucernás & 19,85 & 22,72 & 22,70 & 23,70 & 22,24 \\
\hline b) Lucerna nélküli & 18,35 & 19,17 & 20,60 & 23,05 & 20,29 \\
\hline c) Átlag & 19,10 & 20,95 & 21,65 & 23,37 & \\
\hline d) Főátlag & & & & & 21,27 \\
\hline \multirow{3}{*}{\multicolumn{5}{|c|}{$\begin{array}{l}\text { e) } \mathrm{SzD}_{5 \%} \text { bármely két kombináció között: } \\
\text { f) } \mathrm{SzD}_{5 \%} \text { a tápanyagadagok változatai között a vetésforgók átlagában: } \\
\text { g) } \mathrm{SzD}_{5 \%} \text { a vetésforgók változatai között a tápanyagadagok átlagában: }\end{array}$}} & 2,64 \\
\hline & & & & & 1,86 \\
\hline & & & & & 32 \\
\hline
\end{tabular}

A két különböző vetésforgóban - amellett, hogy mindkét változatban növekedett a talaj szervesanyag-tartalma - az egyes kezelések hatása némileg eltér egymástól (2. táblázat). A mütrágyához kiegészítésként adott istállótrágya szervesanyag-gyarapító hatása a lucerna nélküli vetésforgó a $a_{4}$-kezelésében figyelhető meg, míg ugyanez nem érvényesül ilyen markánsan a lucernás vetésforgóban. Amíg a lucerna nélküli vetésforgóban a szervesanyag-tartalom a tápanyagadagok növekedésével fokozatosan növekszik, addig a lucernás vetésforgóban a kisadagú mütrágyakezelés eredményezi a legjelentősebb növekedést. A tápanyagadag további növelése nem, és a kiegészítésként adott istállótrágya is csak kis mértékben növeli a szervesanyag-tartalmat. A lucernás vetésforgó összes szervesanyag-produkciója felülmúlja a lucerna nélküli forgóét, így érthető, hogy már kisebb tápanyagadagok hatására is akkora a nagyobb mértékü szervesanyag-produkció során talajban visszamaradt szervesanyagtömeg menynyisége, ami már biztosítani tudja hosszú távon az adott talajtípuson a talaj szervesanyag-tartalmának szinten tartását, ill. növelését. Ezzel magyarázható az is, hogy a lucernás vetésforgóban - ami maga felér egy istállótrágyázással (VARGA, 1992) - az istállótrágya hatása nem olyan jelentős, mint a lucerna nélküli vetésforgóban. Ez természetesen nem azt jelenti, hogy ezen a tápanyagellátási szinten a kukorica szemtermésének nagyságára gyakorolt kedvező hatása elhanyagolható lenne. 
A kukorica monokultúra talajában megfigyelt szervesanyag-tartalom növekedés a vetésforgók talajában mért növekedéshez viszonyítva jóval szerényebb mértékü volt és a tápanyagadagok vetésforgó-kísérlethez viszonyított jóval drasztikusabb növelésének hatására következett be. Az eredményekböl kitünik, hogy a kukorica monokultúra talajának szervesanyag-tartalma mindegyik kezelésben jelentősen alulmaradt a vetésforgókhoz viszonyítva.

A kukorica monokultúra kísérletben vizsgált másik tényező - a N-kijuttatás időpontjának - változatai között szignifikáns különbséget nem találtunk (1. táblázat).

A vetésforgók közül a tápanyagkezelések átlagában a lucernát tartalmazó változat eredményezett szignifikánsan nagyobb szervesanyag-tartalmat (lucernás: $22,24 \mathrm{~g} / \mathrm{kg}$, lucerna nélküli: $20,29 \mathrm{~g} / \mathrm{kg}, \mathrm{SzD}_{5 \%}: 1,32 \mathrm{~g} / \mathrm{kg}$ ). Fel kell hívni a figyelmet arra, hogy az a legkisebb szervesanyag-tartalom, ami mindkét vetésforgó trágyázatlan kontrollkezeléseiben ( $\mathrm{a}_{1}$-kezelés) mérhető $(18,35 \mathrm{~g} / \mathrm{kg}$ a lucerna nélküli, ill. $19,85 \mathrm{~g} / \mathrm{kg}$ a lucernás forgóban) jelentősen meghaladják a kukorica monokultúrában $900 \mathrm{~kg} /$ ha NPK tápanyagellátási szinten ( $\mathrm{a}_{4}$-kezelés) mért maximális szervesanyag-tartalmat $(16,3 \mathrm{~g} / \mathrm{kg})$. Az eredmények tehát több szerzővel összhangban (UHLEN, 1991; COLLINS et al., 1992; HAVLIN et al., 1990) tényszerúen alátámasztják a vetésforgók jelentős szerepét a talaj termékenységének fenntartásában, illetve növelésében. Meg kell azonban jegyezni, hogy a kukorica monokultúrában is fenntartható, sőt növelhető a talaj szervesanyag-tartalma kizárólag mütrágya használatával, de a vetésforgókhoz viszonyítva jóval alacsonyabb színvonalon valósítható meg, ami tükröződik a vetésforgókban és a monokultúrában mért kukorica szemtermések közötti különbségben is. A kísérletek szemtermés eredményeit előző közleményünkben ismertettük (TÓTH \& KISMÁNYOKY, 2001).

Más megközelítésben az eredményekkel kapcsolatosan felvetődhet a kérdés, hogy vajon fogalmazhatunk-e úgy, hogy a vetésforgó hatásához viszonyítva a kukorica monokultúrában csökken a talaj szervesanyag-tartalma és a nagyadagú mütrágyázás csak a csökkenés mértékét ellensúlyozza némileg? A kérdés megválaszolásához ismerni kellene a talaj szervesanyag-tartalmát a kísérletek beállításának időpontjában. Ilyen adatok hiányában csak támpontként vehető figyelembe egy szintén a kísérleti téren, de annak egy másik részén Láng Géza által beállított trágyagazdálkodási tartamkísérlet induláskori, 1960-ból származó talajvizsgálati eredménye, mely szerint a talaj $0-20 \mathrm{~cm}$-es rétegében $1,7 \%$ volt a szervesanyag-tartalom (NÉMETH, 1982). A fenti felvetést ezért majd a sokéves adatsorok elemzésekor lehet igazolni vagy cáfolni. Ettől függetlenül a jelenleg rendelkezésre álló adatok alapján a monokultúrával és a vetésforgóval kapcsolatosan levont következtetések hitelesen igazolják a vetésforgóknak és a tápanyagellátásnak a talaj szervesanyag-gazdálkodásában betöltött pozitív szerepét. 
Agronómiai szerkezet

Kukorica monokultúra kísérlet. - A kukorica monokultúra kísérlet talajának agronómiai szerkezetére a nitrogén kijuttatásának változatai nem gyakoroltak statisztikailag kimutatható hatást sem a rög-, sem a morzsa-, sem pedig a porfrakció arányának változását tekintve (3. táblázat).

\section{3. táblázat}

A talaj agronómiai szerkezete kukorica monokultúrában a tápanyagellátás függvényében (Keszthely, 1997)

\begin{tabular}{|c|c|c|c|c|c|}
\hline \multirow[t]{2}{*}{ N-kijuttatás } & \multicolumn{4}{|c|}{$\begin{array}{c}\text { (2) } \\
\text { Tápanyagadagok }\end{array}$} & \multirow[t]{2}{*}{ Átlag } \\
\hline & $\mathbf{a}_{1}$ & $\mathbf{a}_{2}$ & $\mathbf{a}_{3}$ & $\mathbf{a}_{4}$ & \\
\hline \multicolumn{6}{|c|}{ A. Rögfrakció aránya (\%) } \\
\hline a) $\mathrm{N}$ tavasszal egy adagban & 57,57 & 54,29 & 49,48 & 48,11 & 52,36 \\
\hline b) N ősszel egy adagban & 57,66 & 48,77 & 49,18 & 50,45 & 51,52 \\
\hline c) $\mathrm{N}$ tavasszal két adagban & 60,82 & 55,97 & 49,38 & 48,24 & 53,60 \\
\hline d) Átlag & 58,68 & 53,01 & 49,35 & 48,93 & \\
\hline e) Föátlag & & & & & 52,49 \\
\hline \multirow{3}{*}{\multicolumn{5}{|c|}{$\begin{array}{l}\text { f) } \mathrm{SzD}_{5 \%} \text { bármely két kombináció között: } \\
\text { g) } \mathrm{SzD}_{5 \%} \text { a tápanyagadagok változatai között a N-kijuttatás átlagában: } \\
\text { h) } \mathrm{SzD}_{5 \%} \text { a N-kijuttatás változatai között a tápanyagadagok átlagában: }\end{array}$}} & 13,48 \\
\hline & & & & & \\
\hline & & & & & \\
\hline \multicolumn{6}{|c|}{ B. Morzsafrakció aránya (\%) } \\
\hline a) $\mathrm{N}$ tavasszal egy adagban & 39,98 & 44,03 & 46,97 & 48,63 & 44,90 \\
\hline b) N összel egy adagban & 40,06 & 47,56 & 46,03 & 46,36 & 45,00 \\
\hline c) $\mathrm{N}$ tavasszal két adagban & 34,63 & 41,96 & 48,14 & 49,37 & 43,53 \\
\hline d) Átlag & 38,22 & 44,52 & 47,05 & 48,12 & \\
\hline e) Föátlag & & & & & 44,48 \\
\hline \multirow{3}{*}{\multicolumn{5}{|c|}{$\begin{array}{l}\text { f) } \mathrm{SzD}_{5 \%} \text { bármely két kombináció között: } \\
\text { g) } \mathrm{SzD}_{5 \%} \text { a tápanyagadagok változatai között a N-kijuttatás átlagában: } \\
\text { h) } \mathrm{SzD}_{5 \%} \text { a N-kijuttatás változatai között a tápanyagadagok átlagában: }\end{array}$}} & \multirow{3}{*}{$\begin{array}{l}11,95 \\
6,90 \\
5,97\end{array}$} \\
\hline & & & & & \\
\hline & & & & & \\
\hline \multicolumn{6}{|c|}{ C. Porfrakció aránya (\%) } \\
\hline a) $\mathrm{N}$ tavasszal egy adagban & 2,44 & 2,93 & 3,55 & 3,26 & 3,05 \\
\hline b) N ősszel egy adagban & 2,28 & 2,92 & 4,78 & 3,19 & 3,29 \\
\hline c) $\mathrm{N}$ tavasszal két adagban & 2,80 & 2,31 & 2,50 & 2,38 & 2,50 \\
\hline d) Átlag & 2,51 & 2,72 & 3,61 & 2,94 & \\
\hline e) Föátlag & & & & & 2,95 \\
\hline \multirow{3}{*}{\multicolumn{5}{|c|}{$\begin{array}{l}\text { f) } \mathrm{SzD}_{5 \%} \text { bármely két kombináció között: } \\
\text { g) } \mathrm{SzD}_{5 \%} \text { a tápanyagadagok változatai között a N-kijuttatás átlagában: } \\
\text { h) } \mathrm{SzD}_{5 \%} \text { a N-kijuttatás változatai között a tápanyagadagok átlagában: }\end{array}$}} & 3,59 \\
\hline & & & & & \\
\hline & & & & & \\
\hline
\end{tabular}


A mütrágyaadagok növekedésével az agronómiai szerkezet vonatkozásában viszont kedvező folyamatok figyelhetők meg. A N-kijuttatás változatainak átlagában a tápanyagadagok fokozatos növelésének hatására folyamatosan csökken a talajban nemkívánatos rögfrakció $(10 \mathrm{~mm}<)$ aránya. A trágyázatlan kontrollkezelés talajában regisztrált rögfrakció eredményekhez viszonyítva az $\mathrm{NPK}_{600^{-}}$és az $\mathrm{NPK}_{900}$-kezelések eredményeztek szignifikáns csökkenést. Az $\mathrm{NPK}_{600^{-}}$és az $\mathrm{NPK}_{900^{-}}$-kezelések talajában mért rögfrakció arányok között nem volt szignifikáns különbség.

A rögfrakció arányának csökkenésével ellentétben a mütrágyaadagok növekedésével párhuzamosan, fokozatosan növekedett az agronómiai szempontból kívánatos morzsafrakció $(0,25-10 \mathrm{~mm})$ aránya a talajban. A trágyázatlan kontrollkezelés talajában mért értékekhez viszonyítva - a rögfrakció arányának változásával ellentétes tendenciát mutatva - az $\mathrm{NPK}_{600^{-}}$és $\mathrm{NPK}_{900^{-}}$-kezelések talajában szignifikánsan nagyobb volt a morzsafrakció aránya. $\mathrm{Az} \mathrm{NPK}_{600^{-}}$és $\mathrm{NPK}_{900}$-kezelések talajában a morzsafrakció arányok szintén nem különböztek egymástól szignifikánsan.

A talaj agronómiai szempontból nem kívánatos porfrakciója $(<0,25 \mathrm{~mm})$ nem változott szignifikánsan a tápanyagellátási szint emelkedésének hatására kukorica monokultúrában és a rög-, illetve a morzsafrakcióhoz viszonyítva nagyságrendileg kisebb arányt képviselt.

Vetésforgó kisérlet. - A tápanyagadag-növelés hatására a vetésforgó kísérletben szereplő mindkét vetésforgó kukorica szakaszának talajában az agronómiai szerkezet változásának tendenciája a kukorica monokultúra kísérlet talajában megfigyelt változásokhoz hasonlít, ami szintén a szervesanyag-tartalom növekedésével magyarázható.

A tápanyagellátás színvonalának emelkedésével párhuzamosan a vetésforgók kukorica szakaszaiban is csökkent a nemkívánatos rögfrakció, illetve nőtt az agronómiailag kívánatos morzsafrakció aránya a talajban, de sem a rögfrakció arányának a csökkenése, sem pedig a morzsafrakció arányának növekedése nem volt szignifikáns (4. táblázat). A monokultúra talajában mért eredményekhez hasonlóan a tápanyagadagok növekedése a vetésforgók kukorica szakaszainak talajában mért porfrakció arány változására sem hatott szignifikánsan és a porfrakció aránya ebben az esetben is nagyságrenddel kisebb volt a rög-, illetve a morzsafrakció arányához viszonyítva.

A vetésforgó kísérlet kukorica szakaszainak és a kukorica monokultúra kísérlet talajának agronómiai szerkezetét összehasonlítva megállapítható, hogy a trágyázatlan kontrollparcellák talajának a vetésforgókban kedvezőbb volt az agronómiai szerkezete a kisebb rög- és a nagyobb morzsafrakció-tartalom miatt. A tápanyagellátás színvonalának növelésével azonban ezek a különbségek csök- 


\section{4. táblázat}

A talaj agronómiai szerkezete a vetésforgók kukoricaszakaszaiban a tápanyagellátás függvényében (Keszthely, 1997)

\begin{tabular}{|c|c|c|c|c|c|}
\hline \multirow[t]{2}{*}{$\begin{array}{c}\text { (1) } \\
\text { Vetésforgók }\end{array}$} & \multicolumn{4}{|c|}{$\begin{array}{c}(2) \\
\text { Tápanyagadagok } \\
\end{array}$} & \multirow[t]{2}{*}{ Átlag } \\
\hline & $\mathbf{a}_{1}$ & $\mathbf{a}_{2}$ & $\mathbf{a}_{3}$ & $\mathbf{a}_{4}$ & \\
\hline \multicolumn{6}{|c|}{ A. Rögfrakció aránya (\%) } \\
\hline a) Lucernás & 55,90 & 53,54 & 49,89 & 49,16 & 52,12 \\
\hline b) Lucerna nélküli & 51,91 & 51,12 & 49,58 & 48,91 & 50,38 \\
\hline c) Átlag & 53,90 & 52,33 & 49,73 & 49,03 & \\
\hline d) Főátlag & & & & & 51,25 \\
\hline \multirow{3}{*}{\multicolumn{5}{|c|}{$\begin{array}{l}\text { e) } \mathrm{SzD}_{5 \%} \text { bármely két kombináció között: } \\
\text { f) } \mathrm{SzD}_{5 \%} \text { a tápanyagadagok változatai között a vetésforgók átlagában: } \\
\text { g) } \mathrm{SzD}_{5 \%} \text { a vetésforgók változatai között a tápanyagadagok átlagában: }\end{array}$}} & 10,57 \\
\hline & & & & & 7,47 \\
\hline & & & & & 5,29 \\
\hline \multicolumn{6}{|c|}{ B. Morzsafrakció aránya (\%) } \\
\hline a) Lucernás & 42,79 & 43,37 & 48,04 & 48,09 & 45,57 \\
\hline b) Lucerna nélküli & 45,66 & 46,35 & 46,43 & 49,61 & 47,01 \\
\hline c) Átlag & 44,22 & 44,86 & 47,23 & 48,85 & \\
\hline d) Főátlag & & & & & 46,29 \\
\hline \multirow{3}{*}{\multicolumn{5}{|c|}{$\begin{array}{l}\text { e) } \mathrm{SzD}_{5 \%} \text { bármely két kombináció között: } \\
\text { f) } \mathrm{SzD}_{5 \%} \text { a tápanyagadagok változatai között a vetésforgók átlagában: } \\
\text { g) } \mathrm{SzD}_{5 \%} \text { a vetésforgók változatai között a tápanyagadagok átlagában: }\end{array}$}} & 9,75 \\
\hline & & & & & 6,89 \\
\hline & & & & & 4,87 \\
\hline \multicolumn{6}{|c|}{ C. Porfrakció aránya (\%) } \\
\hline a) Lucernás & 1,34 & 3,10 & 2,07 & 2,75 & 2,31 \\
\hline b) Lucerna nélküli & 2,43 & 2,77 & 3,99 & 1,48 & 2,67 \\
\hline c) Átlag & 1,89 & 2,93 & 3,03 & 2,12 & \\
\hline d) Főátlag & & & & & 2,49 \\
\hline \multirow{3}{*}{\multicolumn{5}{|c|}{$\begin{array}{l}\text { e) } \mathrm{SzD}_{5 \%} \text { bármely két kombináció között: } \\
\text { f) } \mathrm{SzD}_{5 \%} \text { a tápanyagadagok változatai között a vetésforgók átlagában: } \\
\text { g) } \mathrm{SzD}_{5 \%} \text { a vetésforgók változatai között a tápanyagadagok átlagában: }\end{array}$}} & 1,81 \\
\hline & & & & & 1,28 \\
\hline & & & & & 0,91 \\
\hline
\end{tabular}

kentek és a legnagyobb tápanyagadagok ( $\mathrm{a}_{3}$ - és $\mathrm{a}_{4}$-kezelések) hatására gyakorlatilag megszüntek.

A két vetésforgó talajának kukorica szakaszokban mért agronómiai szerkezetét összehasonlítva megfigyelhető, hogy a lucernás vetésforgó trágyázatlan kontrollkezelésének talajában nagyobb volt a rög- és kisebb a morzsafrakció aránya a lucerna nélküli vetésforgó kontrollkezelésében mért értékekhez viszonyítva. A tápanyagadagok növekedésével viszont ebben az esetben is jelentős mértékben csökkentek ezek a különbségek. A tápanyagadagok átlagában a lucernás és a lucerna nélküli vetésforgók kukoricaszakaszainak talajában mért 
eredményeket összehasonlítva arra a következtetésre jutottunk, hogy a vetésforgó növényösszetétele nem befolyásolta szignifikánsan a talaj agronómiai szerkezetét. Ha viszont a kukorica monokultúra és a vetésforgó kísérletben mért eredményeket vetjük össze, megfigyelhető, hogy - különösen trágyázás nélkül vagy csak kis tápanyagadagok alkalmazása során - a vetésforgók talajában mért jelentősen nagyobb szervesanyag-tartalom egyúttal kedvezőbb agronómiai szerkezettel is párosult. A földművelési rendszerek megválasztása során tehát hosszú távon mindenképpen érdemes figyelembe venni azok talajra gyakorolt hatását.

A talaj agronómiai szerkezetének vizsgálatát a vetésforgók búzaszakaszainak talajában is elvégezve, a kukoricaszakaszok talajában mért adatokhoz és az azok alapján tett megállapításokhoz viszonyítva némileg eltérő eredményeket kaptunk. Az eredmények alapján - több szerző véleményével egyezően (BIRKÁS, 1993; PERFECT et al., 1990; KEMENESY, 1972 stb.) - arra következtethetünk, hogy a vetésforgó növényösszetételén és az általa befolyásolt talaj szervesanyag-tartalmon túl a termesztett növények egymástól különböző gyökérzete, valamint termesztésük egymástól eltérő agrotechnikája, talajművelési rendszere is jelentősen hatott a talaj agronómiai szerkezetének alakulására.

A vetésforgók búzaszakaszainak talajában a tápanyagellátás szintjének emelkedésével szignifikánsan - a kukoricaszakaszok talajában mért értékekhez viszonyítva jóval nagyobb mértékben - csökkent a rögfrakció aránya (5. táblázat). A nagyadagú $\left(\mathrm{a}_{3}\right)$ mütrágyakezelés hatására szignifikánsan kisebb volt a talaj rögfrakció aránya a trágyázatlan kontroll- $\left(\mathrm{a}_{1}\right)$ és a kisadagú $\left(\mathrm{a}_{2}\right)$ tápanyagkezelés hatásához viszonyítva. A nagyadagú $\left(\mathrm{a}_{3}\right)$ mütrágyakezelésen felül kiegészítésként kijuttatott istállótrágya ( $\mathrm{a}_{4}$-kezelés) szignifikánsan nem csökkentette tovább a talaj rögfrakció tartalmát.

A tápanyagadagok átlagában a vetésforgó változatai közül a lucernás vetésforgó talajában szignifikánsan kisebb volt a rög-, míg szignifikánsan nagyobb volt a morzsafrakció aránya. Kijelenthető tehát, hogy a vetésforgó kukoricaszakaszainak talajában kapott eredményektöl eltérően (ahol a vetésforgók változatai egyik frakció arányában sem okoztak szignifikáns különbséget), a búzaszakaszok talajának agronómiai szerkezete a lucernás vetésforgóban kedvezőbb volt mint a lucerna nélküli vetésforgóban. Meg kell jegyezni azonban, hogy ugyancsak a búzaszakaszokban mérve a morzsafrakcióval együtt a porfrakció aránya is szignifikánsan nagyobb volt a lucernás vetésforgó esetében. Ez az eredmény nem meglepő, hiszen a rögök felaprózódása során a morzsák mellett kis mennyiségü por is képződik. A porfrakció viszont ebben az esetben is jelentősen kisebb arányt képviselt a morzsafrakció mennyiségéhez viszonyítva.

A tápanyagellátás színvonalának emelkedésével a búzaszakaszok talajában a rögfrakció arányának szignifikáns csökkenésével szemben mind a morzsa-, mind pedig a porfrakció aránya szignifikánsan nőtt. A trágyázatlan kontroll- $\left(\mathrm{a}_{1}\right)$ és a kisadagú mütrágyakezelés talajában mért értékekhez viszonyítva a 
kukoricaszakaszának talajában a rög-, a morzsa- és a por frakciók közül legnagyobb hányadot a rögfrakció tett ki (fóátlag: 51,25), addig a búzaszakaszok talajában a morzsafrakció mennyisége dominált (fóátlag: 58,88).

\section{Talajmorzsák vizállósága}

Kukorica monokultúrában a kontrollparcellák ( $\mathrm{a}_{1}$-kezelés) talajában mért értékekhez viszonyítva a kísérletben kijuttatott mindhárom mütrágyaadag $\left(\mathrm{a}_{2}-, \mathrm{a}_{3}-\right.$ és $a_{4}$-kezelések) szignifikánsan csökkentette a vízálló morzsák arányát a talajban (6. táblázat). A hektáronkénti 300-, 600- és 900 kg NPK-mütrágya-adagok

$$
\text { 6. táblázat }
$$

A vízálló talajmorzsák aránya kukorica monokultúrában a tápanyagellátás függvényében (\%) (Keszthely, 1997)

\begin{tabular}{|c|c|c|c|c|c|}
\hline \multirow{2}{*}{$\stackrel{(1)}{\text { N-kijuttatás }}$} & \multicolumn{4}{|c|}{$\begin{array}{c}(2) \\
\text { Tápanyagadagok } \\
\end{array}$} & \multirow{2}{*}{ Átlag } \\
\hline & $\mathbf{a}_{1}$ & $\mathbf{a}_{2}$ & $\mathbf{a}_{3}$ & $\mathbf{a}_{4}$ & \\
\hline a) $\mathrm{N}$ tavasszal egy adagban & 49,27 & 41,10 & 27,80 & 37,00 & 38,79 \\
\hline b) N ősszel egy adagban & 48,05 & 33,77 & 35,65 & 37,72 & 38,80 \\
\hline c) $\mathrm{N}$ tavasszal két adagban & 46,80 & 42,80 & 29,95 & 36,75 & 39,07 \\
\hline $\begin{array}{l}\text { d) Átlag } \\
\text { e) Főátlag }\end{array}$ & 48,04 & 39,22 & 31,13 & 37,16 & 38,89 \\
\hline $\begin{array}{l}\text { f) } \mathrm{SzD}_{5 \%} \text { bármely két kombin } \\
\text { g) } \mathrm{SzD}_{5 \%} \text { a tápanyagadagok } \\
\text { h) } \mathrm{SzD}_{5 \%} \text { a N-kijuttatás válto }\end{array}$ & $\begin{array}{l}\text { között: } \\
\text { zatai kö } \\
\text { között a }\end{array}$ & $\begin{array}{l}\text { t a N-ki } \\
\text { panyag. }\end{array}$ & $\begin{array}{l}\text { atás átle } \\
\text { gok átla }\end{array}$ & $\begin{array}{l}\text { on: } \\
\text { an: }\end{array}$ & $\begin{array}{l}8,27 \\
7,16\end{array}$ \\
\hline
\end{tabular}

egymáshoz viszonyított hatása között nincs szignifikáns különbség. A tápanyagkezelések átlagában a N-kijuttatás változatai nem befolyásolták szignifikánsan a talaj vízálló morzsatartalmát.

A vetésforgó kísérletben a mérések alapján a lucernás vetésforgó talajának morzsafrakciója szignifikánsan vízállóbbnak bizonyult a lucerna nélküli vetésforgó talajának morzsafrakciójához viszonyítva (7. táblázat).

A mütrágyaadagok növelésével csökkent a talaj morzsafrakciójának vízállósága. A vetésforgók változatainak átlagában a kontrollhoz ( $\mathrm{a}_{1}$-kezelés) viszonyítva a nagyadagú $\left(\mathrm{a}_{3}\right)$ mütrágyakezelés hatására szignifikánsan kisebb volt a talajban a vízálló morzsák aránya. A nagyadagú mütrágyakezeléshez kiegészítésként adott istállótrágya ( $\mathrm{a}_{4}$-kezelés) hatására a talaj vízálló morzsáinak aránya ismét a kontrollparcellák talajában mért szinthez közeli értékre emelkedett.

Az eredményekből kitünik tehát, hogy a lucerna és az istállótrágya - vélhetően szervesanyag-gyarapító hatásuknak köszönhetően - kedvező hatást fejt ki a 
talaj vízálló morzsa tartalmára, így a morzsás talajszerkezet stabilizálására. Kísérletünkben a műtrágya+istállótrágyázott $\left(\mathrm{a}_{4}\right)$ kezelésben lucernás vetésforgóban $56,9 \%$, míg a lucerna nélküli vetésforgóban $49,5 \%$ volt a vízálló morzsák aránya. A legnagyobb vízálló morzsatartalmat $(61,62 \%)$ pedig a lucernás vetésforgó trágyázatlan kontrollkezelésében mértük. COOK és ERICSON (1956) (cit. LICHTENEGGER, 1985) agyagos talajon 20 év után azt tapasztalták, hogy kombinált zöld- és istállótrágyázás hatására a vízben stabil morzsaaggregátumok százalékos aránya a kezeletlenhez képest 37,5\%-ról 60,4%-ra emelkedett.

\section{7. táblázat}

A vízálló talajmorzsák aránya vetésforgókban a tápanyagellátás függvényében (\%) (Keszthely, 1997)

\begin{tabular}{|c|c|c|c|c|c|}
\hline \multirow[t]{2}{*}{$\begin{array}{c}\text { (1) } \\
\text { Vetésforgók }\end{array}$} & \multicolumn{4}{|c|}{$\begin{array}{c}(2) \\
\text { Tápanyagadagok }\end{array}$} & \multirow[t]{2}{*}{ Átlag } \\
\hline & $\mathbf{a}_{1}$ & $\mathbf{a}_{2}$ & $\mathbf{a}_{3}$ & $\mathbf{a}_{4}$ & \\
\hline a) Lucernás & 61,62 & 57,72 & 50,75 & 56,90 & 56,75 \\
\hline b) Lucerna nélküli & 49,15 & 51,55 & 44,67 & 49,50 & 48,72 \\
\hline c) Átlag & 55,39 & 54,64 & 47,71 & 53,20 & \\
\hline d) Főátlag & & & & & 52,73 \\
\hline \multirow{3}{*}{\multicolumn{5}{|c|}{$\begin{array}{l}\text { e) } \mathrm{SzD}_{5 \%} \text { bármely két kombináció között: } \\
\text { f) } \mathrm{SzD}_{5 \%} \text { a tápanyagadagok változatai között a vetésforgók átlagában: } \\
\text { g) } \mathrm{SzD}_{5 \%} \text { a vetésforgók változatai között a tápanyagadagok átlagában: }\end{array}$}} & 0,15 \\
\hline & & & & & 7,17 \\
\hline & & & & & 5,07 \\
\hline
\end{tabular}

A vetésforgókban és a kukorica monokultúrában mért értékeket összehasonlítva - RAIMBAULT és VYN (1991) véleményével egyezően - megállapítható, hogy a vetésforgók talajában a vízálló morzsák aránya jelentősen nagyobb a kukorica monokultúra talajában mért adatokhoz viszonyítva. Nagyadagú mütrágyázás hatására viszont mind a vetésforgóban, mind pedig a kukorica monokultúrában romlott a talajmorzsák vízállósága, de ezen kívül mindazok az agrotechnikai tényezők, amelyek növelték a talaj szervesanyag-tartalmát egyértelmüen kedvezően hatottak a talaj agronómiai szerkezetére. A vetésforgók talajában mért nagyobb szervesanyag-tartalom a monokultúra talajához viszonyítva tehát agronómiai szempontból nézve kedvezőbb, tartósabb morzsás talajszerkezettel párosul, amit a különösen napjainkban elötérbe kerülö talajvédelmi problémák megoldásánál célszerű figyelembe venni. 


\section{Összefoglalás}

Ramann-féle barna erdőtalajon (Keszthely) vizsgáltuk vetésforgókban és kukorica monokultúrában a tápanyagellátásnak a talaj szervesanyag-tartalmára, agronómiai szerkezetére és a talajmorzsák vízállóságára gyakorolt hatását. A két vetésforgóban (őszi búza-lucerna-lucerna-őszi búza-kukorica, ill. őszi búza-zabosbükköny-őszi búza-kukorica-szudánifü) kijuttatott tápanyagadagok évről évre az éppen sorra kerülő növénytől függően változnak, de egy teljes rotáció során (5 év alatt) az egyes vetésforgók azonos kezeléseiben kijuttatott tápanyagadagok megegyeznek egymással $(0 ; 520 ; 2080 \mathrm{~kg} \mathrm{NPK} / \mathrm{ha} / 5$ év; 2080 $\mathrm{kg} \mathrm{NPK}+35 \mathrm{t}$ istállótrágya/ha/5 év). A kukorica monokultúra kísérletben a mütrágyaadagok $(0,300,600,900 \mathrm{~kg} \mathrm{NPK} / \mathrm{ha} / \mathrm{év})$ hatása mellett a N-kijuttatás időpontjának (tavasszal egy adagban, ősszel egy adagban, tavasszal két adagban) hatása tanulmányozható.

Az eredmények alapján megállapítható, hogy a kukorica monokultúrához viszonyítva a vetésforgóban nagyobb a talaj szervesanyag-tartalma és azon belül is a növényi összetételnek jelentős hatása van a talaj szervesanyag-tartalmának mennyiségére. A lucernát tartalmazó vetésforgóban mértük a legnagyobb szervesanyag-tartalmat. Az istállótrágya szervesanyag-gyarapító hatása különösen a lucernát nem tartalmazó vetésforgóban volt jelentős. Trágyázással - csupán mütrágyahasználat esetén is - növelhető a talaj szervesanyag-tartalma a nagyobb biomassza-produkció során a területen visszamaradt nagyobb mennyiségü gyökér- és tarlómaradványnak köszönhetően, de ez a növekedés a - a vetésforgóhoz viszonyítva - kukorica monokultúra talajában jóval szerényebb mértékü volt. A nitrogén kijuttatásának időpontja nem befolyásolta szignifikánsan a talaj szervesanyag-tartalmát kukorica monokultúrában.

Az agronómiai szerkezet a tápanyagellátás növekedésével párhuzamosan javult, csökkent a rög- és növekedett a morzsafrakció aránya. A porfrakció aránya jelentősen nem változott kukoricában trágyázás hatására, mennyisége a rög- és morzsafrakcióhoz viszonyítva csekélynek mondható. A trágyázatlan kontrollparcellákon a vetésforgók talajának kedvezőbb volt az agronómiai szerkezete, mint kukorica monokultúrában, de ez a különbség a tápanyagellátás színvonalának emelkedésével csökkent, majd megszünt. A N-kijuttatás időpontjának változatai nem befolyásolták a talaj agronómiai szerkezetét kukorica monokultúrában. A fentieken túl az egyes szántóföldi növények egymástól különböző gyökérzete, valamint termesztésük egymástól eltérő agrotechnikája, talajművelési rendszere is jelentősen hatott a talaj agronómiai szerkezetének alakulására. A vetésforgók őszi búza-szakaszaiban kedvezőbb volt a talaj agronómiai szerkezete, mint kukoricaszakaszaiban. A kukoricaállományban a vetésforgó változatainak a talaj agronómiai szerkezetére gyakorolt hatása között nem volt szignifikáns különbség, az őszibúza-állományban viszont a lucernás vetésforgó ta- 
lajának egyértelmüen kedvezőbb volt az agronómiai szerkezete a lucerna nélküli vetésforgóhoz viszonyítva.

A trágyázatlan kontrollhoz viszonyítva nagyadagú mütrágyázás hatására vetésforgóban és monokultúrában egyaránt romlott a talajmorzsák vízállósága. Vetésforgóban a nagy mütrágyaadaggal együtt kijuttatott istállótrágya (35 t/ha/ 5 év) javította a talajmozsák vízállóságát. A lucernás vetésforgó talajának morzsafrakciója szignifikánsan vízállóbb volt a lucerna nélküli vetésforgó talajának morzsafrakciójához viszonyítva, de a talajmorzsák vízállósága még a lucerna nélküli vetésforgóban is lényegesen jobb volt, mint kukorica monokultúrában. Kukorica monokultúrában a N-kijuttatás időpontjának változatai nem befolyásolták szignifikánsan a talajmorzsák vízállóságát.

Jelen munka az OTKA támogatásával folyt a T016469 és T030768 sz. pályázat keretében.

\section{Irodalom}

Allison, F. E., 1973. Soil Organic Matter and its Role in Crop Production. Elsevier, Amsterdam.

ARMBRUST, D. V. et al., 1982. Dry soil aggregation as influenced by crop and tillage. Soil Sci. Soc. Am. J. 46. 390-393.

BALLENEGGER R. \& DI GLÉRIA J., 1962. Talaj- és trágyavizsgálati módszerek. Mezögazdasági Kiadó. Budapest.

BATHKA, G. R. \& BLAKE, G. R., 1984. Effects of soyabeans on soil propeties related to soil erodability. Soil Sci. Soc. Am. J. 48. 1398-1401.

BIRKÁS M., 1993. Talajmüvelés. In: Földműveléstan (Szerk.: NYIRI L.) 96-194. Mezőgazda Kiadó. Budapest.

CAmPBell, C. A. \& ZentneR, R. P., 1993. Soil organic matter as influenced by crop rotations and fertilization. Soil Sci. Soc. Am. J. 57. 1034-1040.

Caron, J., Kay, B. O. \& Perfect, E., 1992. Short-term decrease in soil structural stability following bromegrass estabilishment on clay silt loam. Plant and Soil. 143. $121-130$.

CHENU, C., 1989. Influence of a fungal polysaccharide, scleroglucan, on clay microstructures. Soil Biol. Biochem. 21. 299-305.

Churchman, G. J. \& TATE, K. R., 1987. Stability of aggregates of different size grades in allophanic soils from volcanic ash in New Zealand. J. Soil Sci. 38. 19-27.

Collins, H. P., Rasmussen, P. E. \& Douglas, C. L., 1992. Crop rotation and residue management effects on soil carbon and microbial dynamics. Soil Sci. Soc. Am. J. 56. $783-788$.

CoOK, L. R. \& ELLIS, B. G., 1987. Soil Management. John Wiley \& Sons, Inc. USA.

CSERHÁTI S., 1905. Növénytermelés I. kötet. Általános növénytermelés. Nitsmann József Nyomdája. Győr. 
DeBRECZENI B., 1994. Tartamtrágyázás hatása a talaj kémhatására. In: Trágyázási kutatások, 1960-1990 (Szerk.: DebrecZeni B. \& DebreceZni B-NÉ). 112. Akadémiai Kiadó. Budapest.

DVORACSEK M., Di GLÉRIA J. \& KLIMES-SZMIK A., 1957. Talajfizika és talajkolloidika. Akadémiai Kiadó. Budapest.

Ellsworth, T. R., Clapp, C. E. \& Black, G. R., 1991. Temporal variations in soil structural properties under corn and soyabean cropping. Soil Sci. 151. 405-416.

FEKETE Z., 1958. Talajtan és trágyázástan. Mezőgazdasági Kiadó. Budapest.

FERTS I., 1955. Termőföld. Mezőgazdasági Kiadó. Budapest.

GYÖRFFY B., 1975. Vetésforgó-vetésváltás-monokultúra. Agrártudományi Közlemények. 34. 61-90.

HAVLIN, J. L. et al., 1990. Crop rotation and tillage effects on soil organic carbon and nitrogen. Soil Sci. Soc. Am. J. 54. 448-552.

HAYNES, R. J. \& SWIFT, R. S., 1990. Stability of soil aggregates in relation to organic constituents and soil water content. J. Soil Sci. 41. 73-83.

HEGEDÜS L., 1980. Talajtani laboratóriumok módszerkönyve. MÉM NAK. Budapest.

KEMENESY E., 1961. A földmüvelés irányelvei. Akadémiai Kiadó. Budapest.

KEMENESY E., 1972. Földmüvelés, talajerőgazdálkodás. Akadémiai Kiadó. Budapest.

KovÁCS K. \& FÜLEKY GY., 1994. A humusztartalom változása barna erdőtalajon. In: Trágyázási kutatások, 1960-1990 (Szerk.: DEBRECZENI B. \& DEBRECEZNI B-NÉ). 121. Akadémiai Kiadó. Budapest.

KovÁTS A. \& ANTAL J., 1992. Tápanyagellátás. In: Szántóföldi növénytermesztés (Szerk.: Bocz E.). 92-111. Mezőgazda Kiadó. Budapest.

LiCHTENEGGER E., 1985. A szántott réteg átszövődése gyökerekkel és ennek jelentősége a vetésforgóban. In: Mezőgazdasági termelés és környezetvédelem. I. (Szerk.: SzABÓ Á.). 106-118. VII. Georgikon Napok. Keszthely.

Miller, R. M. \& JASTROW, J. D., 1992. The role of mycorrhizal fungi in soil conservation. In: Mycorrhizae in sustainable agriculture (Eds.: BETHLENFALVAY, G. J. \& Linderman, R. G.) 21-44. ASA Specific Publication No. 54. Madison, WI.

NÉMETH, I., 1982. Wirkung organischer und anorganischer Düngung auf Ertrag und Bodeneigenschaften. Tag.-Ber., Akad. Landwirtsch.-Wiss. DDR, Berlin. 97-102.

NÉMETH T., 1996. Talajaink szervesanyag-tartalma és nitrogénforgalma. MTA TAKI. Budapest.

PERFECT, E. et al., 1990. Rates of change soil in structural stability under forage and corn. Soil Sci. Soc. Am. J. 54. 179-186.

RaImBAUlT, B. A. \&VYN, T. J., 1991. Crop rotation and tillage effects on corn growth and soil structural stability. Agronomy Journal. 83. 979-985.

SARKADI J., 1975. A mütrágyaigény becslésének módszerei. Mezőgazd. Kiadó. Bpest.

SIPOS G., 1978a. Trágyázás. In: Földműveléstan (Szerk.: LőRINCZ J.). 50-103. Mezőgazdasági Kiadó. Budapest.

SIPOS G., 1978b. A talaj agronómiai jelentősége. In: Földműveléstan (Szerk.: LŐRINCZ J.) 39-44. Mezőgazdasági Kiadó. Budapest.

SIPOS S., 1978. Vetésforgó és vetésváltás. In: Földmüveléstan (Szerk.: LÖRINCZ J.). 267-304. Mezőgazdasági Kiadó. Budapest.

Stefanovits P., 1992. Talajtan. Mezőgazda Kiadó. Budapest. 
TATE, R. L., 1987. Soil Organic Matter. John Wiley \& Sons. Toronto.

TisDAlE, S. L. \& Nelson, W. L., 1966. A talaj termékenysége és a trágyázás. Mezőgazdasági Kiadó. Budapest.

TISDALL, J. M. \& OADES, J. M., 1982. Organic matter and water-stable aggregates in soils. J. Soil Sci. 33. 141-163.

Tóth Z. \& KisMÁNYOKY T., 2001. A kukorica (Zea mays L.) és a búza (Triticum aestivum L.) szemtermésének vizsgálata különböző vetésforgókban és kukorica monokultúrában. Növénytermelés. 50. 123-134.

UHLEN, G., 1991. Long-term effects of fertilizers, manure, straw and crop rotation on total-N and total-C in soil. Acta Agricultura Scandinavia. 41. 119-127.

VÁRALlyAY GY., 1993. A talaj szerkezeti állapotának jellemzése. In: Talaj és agrokémiai vizsgálati módszerkönyv 1. A talaj fizikai, vízgazdálkodási és ásványtani vizsgálata. (Szerk.: BUZÁs I.) 71-82. INDA 4231 Kiadó. Budapest.

VARGA J., 1992. Lucerna. In: Szántóföldi növénytermesztés. (Szerk.: Bocz E.) 735771. Mezőgazda Kiadó. Budapest.

VILJAMSZ, V. R., 1950. A földművelés alapjai. Atheneum Könyvkiadó. Budapest.

Wright, S. F. \& UPADHYAYA, A., 1998. A survey of soils for aggregate stability and glomalin, a glycoprotein produced by hyphae of arbuscular mycorrhizal fungi. Plant and Soil. 198. 97-107.

Wright, S. F., StARR, J. L. \& PAltineanU, I. C., 1999. Changes in aggregate stability and concentration of glomalin during tillage management transition. Soil Sci. Soc. Am. J. 63. 1825-1829.

Wright, S. F., Upadhyaya, A. \& Buyer, J. S., 1998. Comparison of N-linked oligosaccharides of glomalin from arbuscular mycorrhizal fungi and soils by capillary electrophoresys. Soil Biol. Biochem. 30. 1853-1857.

WRIGHT, S. F. et al., 1996. Time course study and partial characterization of a protein on hyphae of arbuscular mycorrhyzal fungi during active colonization of roots. Plant and Soil. 181. 193-203.

YANG, X. M. \& WANDER, M. M., 1988. Temporal changes in dry aggregate size and stability: tillage and crop effects on a silty loam Mollisol in Illinois. Soil and Tillage Research. 49. 173-183.

Érkezett: 2000. december 4. 


\title{
Effect of Fertilization on Soil Organic Matter Content and on the Agronomical Structure of the Soil in Crop Rotations and in Continuous Cropping
}

\author{
Z. TÓTH and T. KISMÁNYOKY
}

Georgikon Faculty of Agricultural Sciences, University of Veszprém, Keszthely

\begin{abstract}
Summary
The relationship of different cropping systems (crop rotations, maize continuous cropping) and fertilizer doses with the soil organic matter content, aggregate size distribution and the water resistance of the soil aggregates was investigated on Ramann's brown forest soil (Eutric Cambisol). The available phosphorus content of this sandy loam soil was low ( $\left(\mathrm{AL}_{-} \mathrm{P}_{2} \mathrm{O}_{5}: 60-80 \mathrm{mg} \mathrm{kg}^{-1}\right)$, the potassium content moderate $\left(\mathrm{AL}-\mathrm{K}_{2} \mathrm{O}: 140-160 \mathrm{mg} \mathrm{kg}^{-1}\right.$ ) and the humus content fairly low (1.6-1.7\%), with a $\mathrm{pH}(\mathrm{KCl})$ value of 7.3 . The long-term annual mean precipitation was $700 \mathrm{~mm}$, but the distribution was often unfavourable. The average number of rainy days was 161 , with a mean annual temperature of $10.8^{\circ} \mathrm{C}$.

The study was conducted in long-term field experiments set up in Keszthely, Hungary in 1963 (crop rotation) and 1969 (maize continuous cropping). The bi-factorial trials were arranged in randomized complete block (crop rotation) and split plot (maize continuous cropping) designs with four replications. The study was conducted on the maize and winter wheat grown in two different types of five-year crop sequences (winter wheat-alfalfa-alfalfa-winter wheat-maize; winter wheat-oats and vetch-winter wheat-maize-sorghum) and in the maize continuous cropping, and involved four fertilizer treatments (crop rotation: $\mathrm{a}_{1}:$ control, $\mathrm{a}_{2}: 520 \mathrm{~kg} \mathrm{NPK} / \mathrm{ha}^{-1} 5 \mathrm{yr}^{-1}, \mathrm{a}_{3}: 2080 \mathrm{~kg}$ NPK ha ${ }^{-1} 5 \mathrm{yr}^{-1}, \mathrm{a}_{4}: 2080 \mathrm{~kg}$ NPK $+35 \mathrm{t}$ farmyard manure $\mathrm{ha}^{-1} 5 \mathrm{yr}^{-1}$; continuous cropping: $\mathrm{a}_{1}$ : control, $\mathrm{a}_{2}: 300 \mathrm{~kg} \mathrm{NPK} \mathrm{ha}^{-1} \mathrm{yr}^{-1}, \mathrm{a}_{3}: 600 \mathrm{~kg} \mathrm{NPK} \mathrm{ha}^{-1} \mathrm{yr}^{-1}, \mathrm{a}_{4}: 900 \mathrm{~kg}$ NPK $\mathrm{ha}^{-1} \mathrm{yr}^{-1}$ ). In the crop rotations farmyard manure was applied before maize every fifth year. In addition to the fertilizer rates, the effect of the timing of $\mathrm{N}$ application (once in spring, once in autumn, twice in spring) can also be studied in the maize continuous cropping experiment.

Soil samples were collected at $30 \mathrm{~cm}$ depth. The organic matter content was quantified by Tyurin's method while the aggregate size distribution was determined by sieving. The aggregates were separated into three groups $(<0.25 \mathrm{~mm}$ : dust; $0.25-10 \mathrm{~mm}$ : crumb; $>10 \mathrm{~mm}$ : clod). The water resistance of the soil aggregates was determined by wet sieving. Analysis of variance was used to test the statistical significance of the treatments.

The results of the study can be summarized as follows:

- In the crop rotations the soil organic matter content was greater than in maize continuous cropping. The highest organic matter content was registered in the crop rotation containing alfalfa.

- Soil organic matter content increased parallel with the rise in fertilizer rates. Farmyard manure had a positive effect on the organic matter content especially in the crop rotation without alfalfa.
\end{abstract}


- The aggregate size distribution of the soil improved parallel with the increase in fertilizer rates in each trial, and was better in crop rotation than in maize continuous cropping; furthermore, the aggregate size distribution of the soil was more favourable in winter wheat than in maize.

- The water resistance of the soil aggregates was the best in the crop rotation containing alfalfa and the worst in continuous cropping.

- With the rise in fertilizer rates the water resistance of the soil aggregates deteriorated, while farmyard manure had a positive effect.

Table 1. Organic matter content of the soil in continuous maize cropping as a function of fertilizer rates $\left(\mathrm{g} \mathrm{kg}^{-1}\right)$ (Keszthely, 1996). (1) Timing of $\mathrm{N}$ application. a) $\mathrm{N}$ in one dose in spring, b) $\mathrm{N}$ in one dose in autumn, c) $\mathrm{N}$ in two doses in spring, d) Mean, e) Grand mean, f) $\operatorname{LSD}_{5 \%}$ between any two combinations, g) $\mathrm{LSD}_{5 \%}$ between the variants of the fertilizer rates as averaged over the timing of $\mathrm{N}$ application, $\mathrm{h}$ ) $\mathrm{LSD}_{5 \%}$ between the variants of the timing of $\mathrm{N}$ application as averaged over the fertilizer rates. (2) Fertilizer rates. (3) Mean.

Table 2. Organic matter content of the soil in crop rotations as a function of fertilizer rates $\left(\mathrm{g} \mathrm{kg}^{-1}\right)$ (Keszthely, 1996). (1) Crop rotations. a) Includes alfalfa, b) Does not include alfalfa, c) Mean, d) Grand mean, e) LSD $_{5 \%}$ between any two combinations, f) $\mathrm{LSD}_{5 \%}$ between the variants of the fertilizer rates as averaged over the crop rotations, g) $\mathrm{LSD}_{5 \%}$ between the variants of the crop rotations as averaged over the fertilizer rates. (2)-(3): see Table 1.

Table 3. Aggregate size distribution of the soil in continuous maize cropping as a function of fertilizer rates (Keszthely, 1997). (1)-(3): see Table 1. A. Proportion of clod fraction, \%. B. Proportion of crumb fraction, \%. C. Proportion of dust fraction, \%.

Table 4. Aggregate size distribution of the soil in the maize courses of crop rotations as a function of fertilizer rates (Keszthely, 1997). (1)-(3): see Table 2. A. Proportion of clod fraction, \%. B. Proportion of crumb fraction, \%. C. Proportion of dust fraction, $\%$.

Table 5. Aggregate size distribution of the soil in the winter wheat courses of crop rotations as a function of fertilizer rates (Keszthely, 1993). (1)-(3): see Table 2. A. Proportion of clod fraction, \%. B. Proportion of crumb fraction, \%. C. Proportion of dust fraction, $\%$.

Table 6. Proportion of water-resistant aggregates of the soil in continuous maize cropping as a function of fertilizer rates (\%) (Keszthely, 1997). (1)-(3): see Table 1.

Table 7. Proportion of water-resistant aggregates of the soil in crop rotations as a function of fertilizer rates (\%) (Keszthely, 1997). (1)-(3): see Table 2. 